\title{
Deagglomeration of aerosil in polishing suspension for chemical-mechanical polishing of sapphire
}

\author{
E.A.Vovk \\ Institute for Single Crystals, STC "Institute for Single Crystals", National \\ Academy of Sciences of Ukraine, 60 Lenin Ave., 61001 Kharkiv, Ukraine
}

\section{Received November 22, 2014}

\begin{abstract}
Studied is the influence of $\mathrm{pH}$, surface-active substances and ultrasonic dispersing on the degree of deagglomeration of aerosol in the polishing suspensions used for CMP of sapphire, the removal rate and the optical quality of the surface at polishing. Ultrasonic dispersing makes it possible to obtain silica sol. It is established that the addition of high-molecular compounds with the functional groups $\mathrm{OH}$ favors deagglomeration of aerosil, raises the removal rate and allows to obtain the sapphire surface with the optical quality 20/10-40/20 according to the USA standard MIL-0-13830.

Keywords: sapphire, chemical-mechanical polishing, polishing suspension, silica, aerosil, deagglomeration

Изучено влияние $\mathrm{pH}$, поверхностно-активных веществ и ультразвукового диспергирования на степень деагломерации аэросила в полировальной суспензии для химикомеханического полирования сапфира, скорость съема сапфира и оптическое качество поверхности при полировании. В результате ультразвукового диспергирования суспензии получен силикозоль. Установлено, что добавка в полировальную суспензию высокомолекулярных соединений с функциональными группами ОН способствует деагломерации аэросила, повышению скорости съема и позволяет получать поверхности сапфира с оптическим качеством 20/10-40/20 по стандарту USA MIL-0-13830.
\end{abstract}

Деагломерація аеросилу у полірувальній суспензії для хіміко-механічного полірування сапфіру. О.О.Вовк.

Досліджено вплив $\mathrm{pH}$, поверхнево-активних речовин та ультразвукового диспергування на ступінь деагломерації аеросилу у полірувальні суспензії для хіміко-механічного полірування сапфіру, швидкість знімання сапфіру та оптичну якість поверхні при поліруванні. В результаті ультразвукового диспергування суспензії одержано сілікозоль. Встановлено, що використання у полірувальній суспензії високомолекулярних сполук з функціональними групами ОН призводить до деагломерації аеросилу, підвищення швидкості знімання та дозволяє отримувати поверхні сапфіру з оптичною якістю 20/10-40/20 за стандартом USA MIL-0-13830.

\section{Introduction}

Sapphire is widely used in opto- and microelectronics in the capacity of optical windows and substrates for epitaxy. Such products must satisfy high technical requirements to the structure perfection and optical quality of the surface. For instance, to achieve high reflection coefficients of the elements of X-ray optics, their surface roughness must not be worse than several tenths of a nanometer [1]. At the obtaining of "silicon-on-sapphire" structures and heterostructures based on nitrides of the third group metals (InN, GaN, AIN) and their solid solutions essential roughness may give rise 
to three-dimensional growth or amorphization of the layer [2-4]. The substrate surface must not have damaged surface-adjacent layer and defects, its roughness $R a$ is not to be higher than $0.3 \mathrm{~nm}$, the optical purity class must be $20 / 10$ (according to the USA standard MIL-0-13830).

The method most often applied for final polishing of sapphire surface is chemicalmechanical polishing (CMP) using colloidal silicon dioxide as a polishing suspension [58]. CMP allows to obtain surfaces of high optical quality not containing surface and surface-adjacent defects, and is characterized by high rate of the material removal. The technologies which imply the use of stabilized silica sols produced by Nalco Company (USA) in the capacity of polishing solution are most widespread in the world $[9,10]$. Silicon dioxide is present in these silica sols in the form of individual spherical particles, which size varies from 7 to $100 \mathrm{~nm}$ depending on the sol sort (Fig. 1a). Another, much less expensive method of CMP, is the use of polishing suspension on the base of silicon dioxide in the form of aerosil obtained by pyrogenic synthesis [11]. This aerosil consists of silicon dioxide particles with a grain size of 7$40 \mathrm{~nm}$ and is strongly agglomerated. Hard aggregates formed from nanodimensional particles sintered in the process of hightemperature pyrogenic synthesis, create agglomerates both at the synthesis and in water suspension, due to interparticle interaction forces. Agglomeration of aerosil in water is also provided by the silanole groups $\equiv \mathrm{Si}-\mathrm{OH}$ present on the particle surface which form hydrogen bonds. The size of coral-like agglomerates reaches several microns (Fig. 1b). Their presence leads to the formation of scratches on the polished surface and to diminution of the polishing rate. Such a polishing suspension can be used for CMP of sapphire with a considerable deviation (exceeding 3 ang.deg.) of the surface from the crystallographic plane. However, the class of the surface optical purity will be not higher than 40/20. At lesser deviation angles and the crystallographic orientation (0001) the quality of the polished surface essentially worsens [12]. To raise the surface quality it is necessary to improve the chemical and dispersion composition, as well as the rheological properties of the polishing suspension. The latter must be stable, low-viscous and contain non-agglomerated nanodimensional $\mathrm{SiO}_{2}$ particles chemically active to $\mathrm{Al}_{2} \mathrm{O}_{3}$.
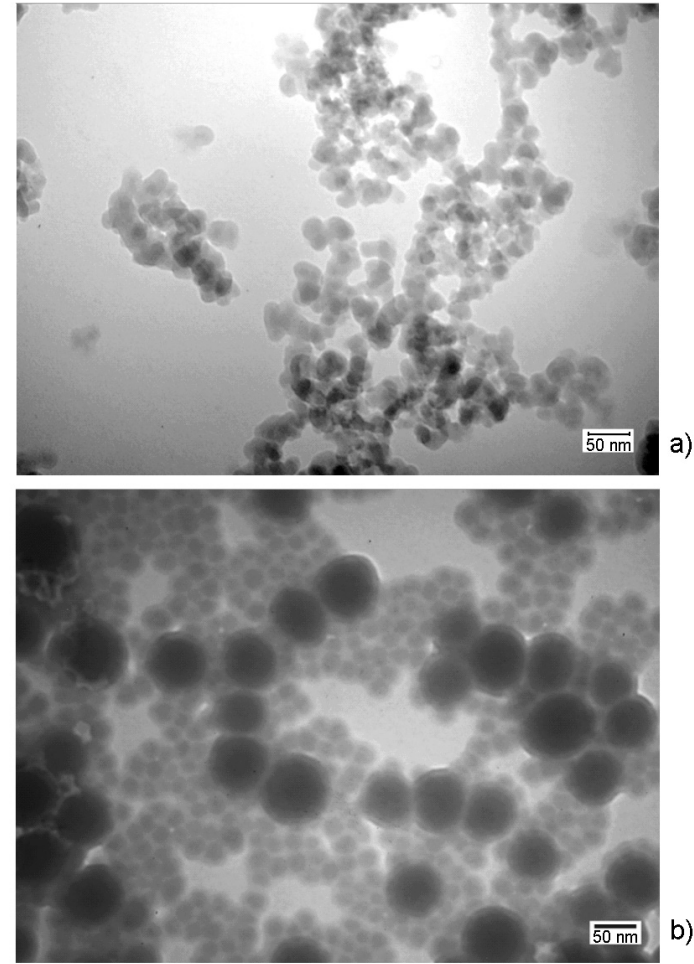

Fig. 1. Polishing suspension: (a) agglomerated on the base of aerosil, (b) silica sol Nalco 2360 (consists of the particles of two fractions 20 and $70 \mathrm{~nm}$ ) (TEM, the mark at $50 \mathrm{~nm})$.

The goal of the present study is establishment of the conditions of the destruction of aerosil agglomerates (deagglomeration) in the polishing suspension used for chemical-mechanical polishing of sapphire which allows to obtain the surface of high optical quality.

\section{Experimental}

The experiments were performed on $\varnothing 70 \times 3 \mathrm{~mm}$ sapphire disks with the crystallographic orientations of the surface (0001), (10T2), (1120). The samples were mechanically polished by means of the diamond paste ACM 28/20 and then subjected to CMP in aerosil suspension. The process of pol ishing was realized on a special faceplate which allowed to simultaneously treat three samples under the same conditions. The rate of CMP was quantitatively estimated based on the removal rate of sapphire calculated from the loss of the sample mass according to the procedure described in detail in [12].

The polishing suspension was prepared from aerosil with a specific surface of $380 \mathrm{~m}^{2} / \mathrm{g}$ (produced in Ukraine) and deionized water. The content of aerosil in the 
suspension was 5 wt.\%, that corresponded to the optimum one [13].

Deagglomeration of aerosil is rather difficult, since destruction of the agglomerates requires essential energy. As known from the literature, pyrogenic silicon dioxide cannot be used for preparation of an ideal sol consisting of discrete particles. However, it can be partially deagglomerated by means of certain chemical and mechanical treatment, as well as dispersers [14]. Deagglomeration of aerosil and stabilization of its suspension may be provided due to the following two factors. The first of them is bound up with the formation of ion charges on the particles which will lead to their separation by means of repulsive forces (electrostatic stabilization). The second factor is adsorption of inert surface-active substances (SAS) which allows to separate the surfaces of the particles for preventing possible direct contacts between the silanol groups $\equiv \mathrm{Si}-\mathrm{OH}$ (steric stabilization).

In this study electrostatic stabilization was realized by the addition of alkaline agent to the suspension. We prepared the suspensions with $\mathrm{pH}$ varying in the range from 4.5 to 11 . The value of $\mathrm{pH}$ was controlled using $0.5 \mathrm{M} \mathrm{NaOH}$ solution. The SAS solutions were added to the suspension at constant mixing. The suspension was homogenized by means of a mechanical mixer rotating at a velocity of 1200 r.p.m. during two hours.

The suspension viscosity was measured by a glass viscosimeter at $20^{\circ} \mathrm{C}$. Ultrasonic dispersing was realized in a bath of ELMA $\mathrm{T} 700 / \mathrm{H}$ type (with a working frequency of $36 \mathrm{kHz}$ and a power of $560 \mathrm{wt}$ ) containing 11 of the polishing suspension. The morphology of the aerosil particles was studied on a transmission electron microscope EM125 with $100 \mathrm{kV}$ accelerating voltage. The optical quality of the surface was estimated visually using an optical microscope MBS-2.

\section{Results and discussion}

As found while investigating the morphology of the aerosil particles, at $\mathrm{pH}$ increasing from 4.5 to 8 the size of the agglomerates diminishes almost by an order. The study of the removal rate of sapphire in the process of CMP shows that it rises with $\mathrm{pH}$ and reaches its maximum at $\mathrm{pH} 8.4$ for all the crystallographic orientations (Fig. 2). Such a dependence on $\mathrm{pH}$ may be caused by diminution of the size of the aerosil particles which results in the increase of the area of the surface of the

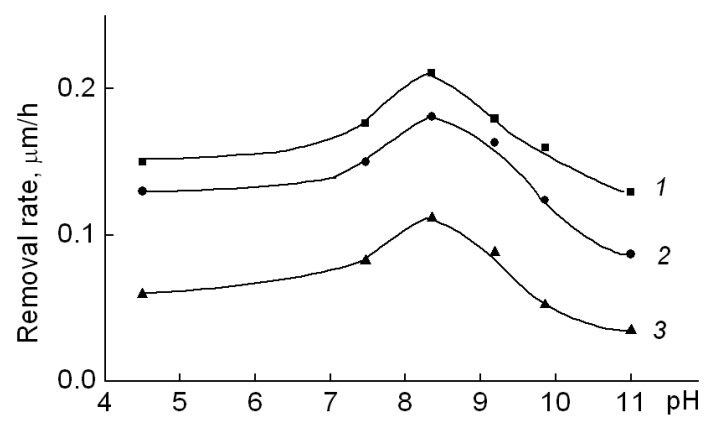

Fig. 2. Dependences of the removal rate for sapphire with the crystallographic orientation of the surface $1-(0001), 2-(1012), 3-$ (1120) on $\mathrm{pH}$ of the polishing suspension.

contacts between $\mathrm{SiO}_{2}$ and sapphire. The maximum of the graph may be connected with the change of the reaction of chemical interaction between $\mathrm{Al}_{2} \mathrm{O}_{3}$ and $\mathrm{SiO}_{2}$ in accordance with the model proposed in our paper [10]. The two competing chemical reactions which proceed between $\mathrm{Al}_{2} \mathrm{O}_{3}$ and $\mathrm{SiO}_{2}$ depending on $\mathrm{pH}$ lead to the formation of amorphous $\mathrm{Al}_{2} \mathrm{SiO}_{5}$ layer on the sapphire surface.

The change of the chemical reaction is caused by the fact that the charge state of the sapphire surface undergoes the changeover from $\mathrm{Al}^{3+}$ to $\mathrm{AlO}_{2}^{-}$, since the isoelectric point of $\mathrm{Al}_{2} \mathrm{O}_{3}$ is at $\mathrm{pH}$ 7.9. However, irrespective of the increase of the removal rate, one could observe surface defects (scratches) on the surface of sapphire, particularly of the one with the orientation (0001).

We tested several non-ionogenic highmolecular SAS with different form of the functional group and polymer chain length: oxyethyl derivatives (OD-7), gelatin, SAS1 and SAS2 with $\mathrm{OH}$-groups differing in molecular mass $\left(M_{\mathrm{SAS} 1}=25000, M_{\mathrm{SAS} 2}=\right.$ 250000). To establish the optimum SAS concentration there were prepared series of suspensions with SAS concentrations ranging between 0.05 and 2 wt. $\%$ with respect to silicon dioxide. Presented in Fig. 3 are the results of comparative study of the morphology of the aerosil particles and the removal rate of sapphire for the suspensions with different SAS. The suspensions with OD-7 and gelatin were found to be the least effective, as they were strongly agglomerated and provided low removal rate. The suspension containing gelatin had high viscosity, and at its concentration of 1 mass. $\%$ there occurred slipping of the samples on the polishing pad practically without friction. Therefore, the process of polishing 
a)

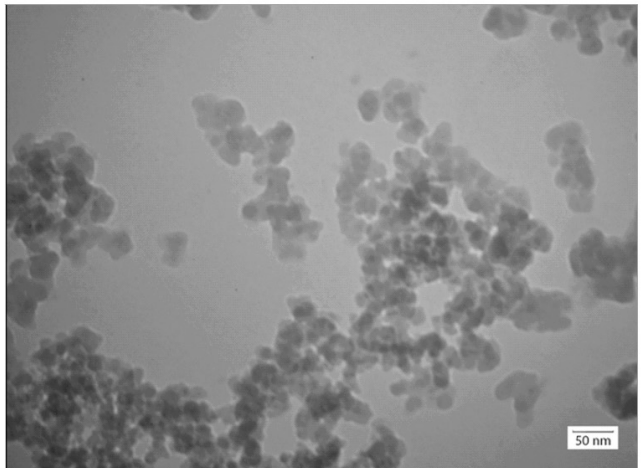

b)

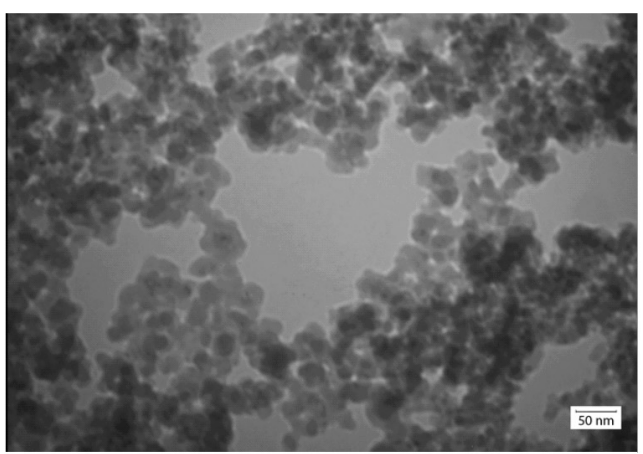

c)

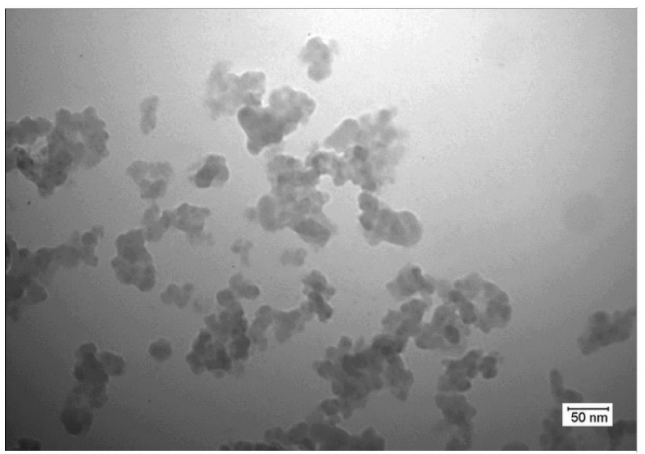

d)

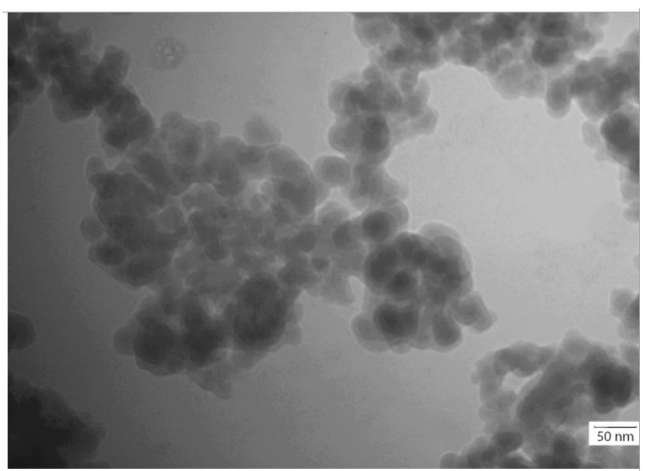

OD-7
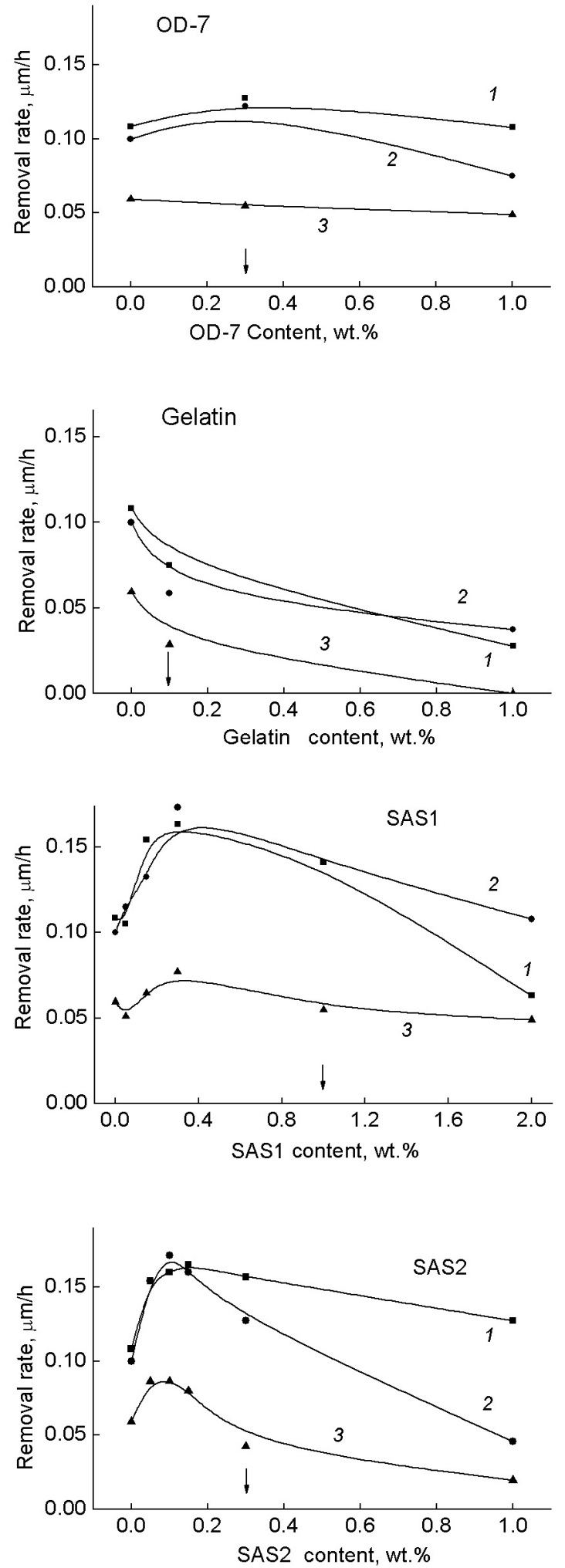

Fig. 3. Morphology of aerosil particles (from the left) and dependences of the removal rate for sapphire with the crystallographic orientation of the surface $1-(0001), 2-(10 \mathrm{~T} 2), 3-(1120)$, on the content of SAS in the polishing suspension (from the right). The arrows show SAS concentrations in the suspensions presented in the microphotographs (TEM, the mark at $50 \mathrm{~nm}$ ). 


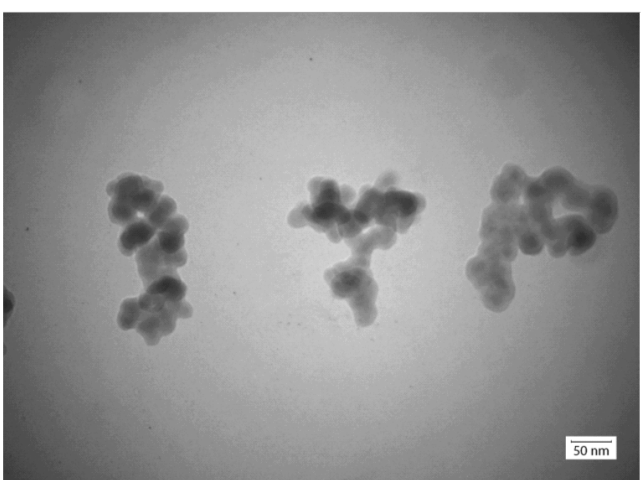

a)

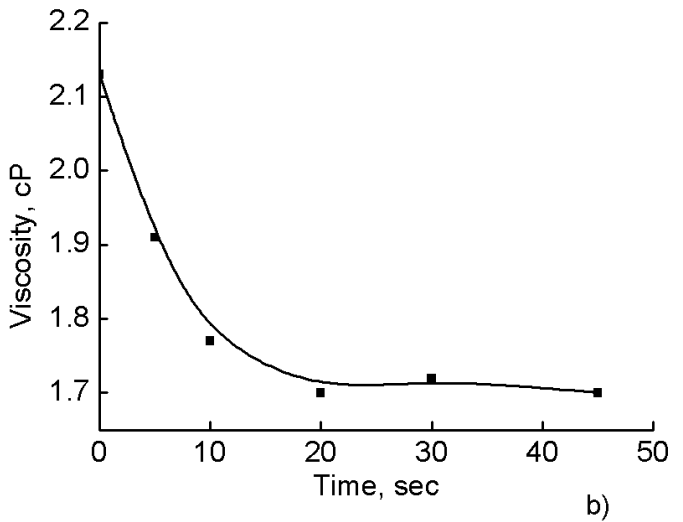

b)

Fig. 4. Polishing suspension on the base of aerosil at ultrasonic treatment: (a) morphology of the particles of aerosil after the treatment during $45 \mathrm{~min}$, (b) dependence of the suspension viscosity on the duration of dispersing.

terminated, and the removal rate diminished to 0 (Fig. 3b). The polishing quality was extremely low.

For the suspensions with SAS1 and SAS2 the results were similar (Fig. 3c, d). However, the same removal rates were achieved at SAS2 concentrations almost half as high, obviously due to the longer polymer chain. At the use of the suspensions containing SAS with concentrations $0.2-1.4$ wt. $\%$ and 0.05-0.3 wt. $\%$ for SAS1 and SAS2, respectively, the quality of the surface corresponded to the optical purity classes $20 / 10-$ $40 / 20$, depending on the crystallographic orientation of the sapphire surface as well as the SAS type and concentration. The best surface quality was obtained for the suspension with SAS1 in which the aerosil particles were least agglomerated. At the same time, the results of the measurement of the suspension viscosity show that at the rise of the SAS1 content from 0 to 1 wt. $\%$ the viscosity grows from 2.12 to $3.02 \mathrm{cP}$. This testifies to the fact that along with aerosil deagglomeration, there takes place agglutination of long polymer chains that impedes the reciprocal motion of the particles [11]. Apparently, SAS which covers the aerosol particles also acts as a lubricant preventing the formation of defects caused by the presence of coarse particles in the polishing suspension, defects of the polishing pad, as well as by noise and minor vibrations from the polishing equipment. Similar effect was reported by the authors who applied carboxylic acid as a lubricant in the process of polishing hard disks using colloidal $\mathrm{SiO}_{2}$ [15].

All the suspensions with different $\mathrm{pH}$ and SAS were unstable and formed gelatinous sediment in the course of time.
For the polishing suspension deagglomeration we used dispersing in ultrasonic bath. In the process of ultrasonic treatment the suspension transparency increased, whereas its viscosity diminished from 2.13 to $1.7 \mathrm{cP}$ (Fig. 4b). Within $20 \mathrm{~min}$. of dispersing the suspension was transparent and stable, no sediment was formed at storage during several weeks. The said testifies to the formation of a stable sol which consists of aggregates with an average size up to $150 \mathrm{~nm}$ (Fig. 4a).

In the process of polishing by means of this suspension the removal rate for all the crystallographic orientations of sapphire increased in comparison with the one in the case of treatment in non-dispersed suspension. At the same time, vibration of the polishing equipment became stronger. The quality of the sample surface was lower than that obtained while polishing in the suspension containing SAS1 and SAS2. This fact confirms the assumption that some part of the defects present on the surface of sapphire may arise in the process of mechanical interaction of sapphire surface with the aerosil particles and the material of polishing pad.

\section{Conclusions}

Studied is the influence of $\mathrm{pH}$, surfaceactive substances and ultrasonic dispersing on the degree of deagglomeration of aerosol in the polishing suspensions used for CMP of sapphire, the removal rate and the optical quality of the surface. It is established that with the rise of $\mathrm{pH}$ the size of the agglomerates diminishes, the removal rate reaches its maximum at $\mathrm{pH}$ 8.4. Ultrasonic dispersing of the suspension containing aerosil makes it possible to obtain a silica 
sol with secondary silicon dioxide particles measuring up to $150 \mathrm{~nm}$. It is found that the addition of SAS with functional groups $\mathrm{OH}$ in concentrations of $0.05-1.4$ wt. $\%$ to the polishing suspension leads to deagglomeration of aerosil, increases the removal rate and allows to obtain the surface of sapphire with the optical quality $20 / 10-40 / 20$.

\section{References}

1. K.Murakami, T.Oshino, H.Kondo et al., Proc. SPIE, 6921, 69210Q (2008).

2. V.I.Osinskii, T.I.Goncharenko, N.N.Ljahova, PSE, 1, 94 (2003).

3. N.M.Shmidt, A.A.Ankudinov, S.J.Belova et al., Svetodiody i Lasery, 1-2, 38 (2003).

4. J.Cui, A.Sun, M.Reshichkov et al., MRS Internet J.Nitride Semiconductor.Res., 5, e7 (2000).

5. Niu Xin-huan, Liu Yu-ling, Tan Bai-mei, Trans. Nonferrous Met.Sjc.China, 16, s732 (2006).
6. V.V.Rogov, N.D.Rublev, T.L.Krotenko et al., Sverhtverd. Materialy, 4, 75 (2008).

7. H.Aida, T.Doi, H.Takeda et al., Current Appl. Phys., 12, S41 (2012).

8. W.Xu, X.Lu, G.Pan et al., Appl.Surf.Sci., 256, 3936 (2010).

9. U.S. Patent 4,054,536 (1977).

10. U.S. Patent 4,806,665 (1989).

11. R.K.Iler, The Chemistry of Silica: Solubility, Polymerization, Colloid and Surface Properties and Biochemistry of Silica, A Wiley-Interscience Publication, New YorkChichester-Brisbano-Toronto (1979).

12. A.T.Budnikov, E.A.Vovk, S.I.Krivonogov et al., Functional Materials, 17, 488 (2010).

13. E.A.Vovk, A.T.Budnikov, M.V.Dobrotvotskaya et al., J.Surf. Investig., X-Ray, Synchrotron and Neutron Techn.

, 6, 115 (2012).

14. J.Eisenlauer, E.Killmann, J.Colloid and Interface Sci., 74, 108 (1980).

15. H.Lei, J.Luo, Wear, 257, 461 (2004). 